\title{
MANAJEMEN MUTU GURU PONDOK PESANTREN
}

\author{
Ruma Mubarok \\ e-mail : ruma_mubarak@yahoo.com \\ Fakultas Ilmu Tarbiyah dan Keguruan \\ UIN Maulana Malik Ibrahim Malang
}

\section{Abstract}

Islamic boarding schools in Indonesia as an educational institution of its existence is enough very old. Along the way, many changes occur, both positive and negative. But the development of the boarding school in the archipelago as the oldest educational institution does not have a significant correlation with the strength or menejemennya progress. Boarding schools have ups and downs, from the colonial period, independence, until the time of the current reform. Kyai as a helm, multifunctional duties, as a teacher, preacher, and managers. As a manager it must improve the quality mutu.Tuntutan better than any cleric become a requirement for boarding institutions. Quality in the sense of the word, they can work with professionals, in accordance with the functions and responsibilities. So also for the leadership of the boarding school can work in a professional manner to meet the needs of the professionalism of teachers, good service, education, health, facilities, and no less important is the economic aspect or the necessities of life of current and future.

Keywords: Quality management, ustadz, pesantren

\section{Abstrak}

Pondok pesantren di Indonesia sebagai lembaga pendidikan keberadaannya sudah cukup sangat tua. Dalam perjalanannya, banyak perubahan-perubahan yang terjadi, baik positif maupun negatif. Namun Perkembangan pondok pesantren di nusantara sebagai lembaga pendidikan tertua tidak memiliki korelasi yang signifikan dengan kekuatan atau kemajuan menejemennya. Pondok pesantren mengalami pasang surut, dari zaman penjajahan, kemerdekaan, sampai zaman reformasi saat ini. Kyai sebagai seorang pucuk pimpinan, tugasnya multifungsi, sebagai guru, muballigh, sekaligus manajer. Sebagai seorang manajer maka harus meningkatkan mutu.Tuntutan mutu yang lebih baik dari setiap ustadz menjadi kebutuhan bagi lembaga pesantren. Mutu dalam arti kata, mereka dapat bekerja dengan profesional, sesuai dengan fungsi dan tanggungjawab. Begitu juga bagi pimpinan pondok pesantren dapat bekerja secara profesional untuk memenuhi kebutuhan profesionalisme para ustadz, baik pelayanan, pendidikan, kesehatan, fasilitas, dan yang tidak kalah penting adalah aspek ekonomi atau kebutuhan hidup saat ini dan masa akan datang

Kata kunci: Manajemen mutu, ustadz, pesantren

\section{Pendahuluan}

sebagai lembaga pendidikan

keberadaannya sudah cukup sangat tua.

Dalam perjalanannya, banyak perubahan-

perubahan yang terjadi, baik positif maupun negatif. Dilihat dari proses peubahan dan transformasi pondok pesantren dapat dibedakan menjadi tiga corak, yaitu pertama; pesantren tradisional, pesantren yang masih mempertahankan nilai-nilai tradisionalnya dan tidak mengalami transformasi yang berarti dalam sistem pendidikannya. Kedua; pesantren tradisional, namun sudah mulai 
mengadopsi sistem pendidikan modern, tetapi tidak sepenuhnya. Dan ketiga; pesantren modern yaitu pesantren yang telah mengalami transformasi secara signifikan, baik sistem pendidikannya maupun unsur-unsur kelembagaannya. (Samsul Nizar, 289-290)

Namun Perkembangan pondok pesantren di nusantara sebagai lembaga pendidikan tertua tidak memiliki korelasi yang signifikan dengan kekuatan atau kemajuan menejemennya. (Mujammil Qomar, 59) Pondok pesantren mengalami pasang surut, dari zaman penjajahan, kemerdekaan, sampai zaman reformasi saat ini.

Pada dasarnya pondok pesantren di Indonesia menekankan sikap konservatif yang bersandar dan berpusat pada figur kyai dan berdiri dengan harta kekayaan kyai sendiri, tidak ada campur tangan pemerintah sedikit pun. (Malik Fajar, 219) .Oleh karena itu, segala urusan dan manajemen pondok pesantren pada dasarnya hak prioritas kyai.

Kebanyakan pesantren menganut pola "serba mono", monomanajemen dan monoadministrasi sehingga tidak ada delegasi kewenangan ke unit kerja lain yang ada dalam organisasi. (M. Sulthon Masyhud dan Moh. Khunuridho, 115). Oleh karena itu, pesantren pada umumnya sampai sekarang ini dalam pengelolaannya lebih kepada tradisi yang dipertahankan dari dahulu, bukan di dasarkan pada perkembangan dunia dan profesionalisme individu dalam mengembangkan pondok pesantren. Semuanya dianggap sakral dari pendiri awal, sehingga apa pun yang bersifat pembaharuan dianggap menyimpang dari tradisi salafiyah.

Namun kyai sebagai seorang pucuk pimpinan, tugasnya multifungsi, sebagai guru, muballigh, sekaligus manajer (Hamdan Farchan dan Syarifuddin, 51). Tapi dalam peranannya yang lebih praktis adalah sebagai seorang mu'allim (pengajar) yang mewariskan keilmuannya secara "ikhlas" demi meninggikan kalimat La Ilaha Illa Allah.
Pada zaman ini, dengan masa dan kehidupan yang berbeda dari masa lalu, maka perubahan pendidikan Islam harus berbeda dan orientasi berpikir pun harus berbeda. Maka pondok pesantren dengan pucuk pimpinan pada kyai sebagai sentral, otoritatif, dan pusat seluruh kebijakan dan perubahan juga harus dapat melakukan perubahan-perubahan dalam sistem, walaupun tidak merubah secara total tradisi pesantren yang sejak semula sudah menjadi unggulan. (Sulthon Masyhud, 1415)

Perubahan yang diinginkan adalah perubahan lebih baik terutama dalam memandang para pengasuh terutama guru atau ustadz yang menjadi motor penggerak di dalam pondok pesantren, sehingga kegiatan 24 jam pondok pesantren dalam berjalan dengan baik.

Tuntutan mutu yang lebih baik dari setiap ustadz menjadi kebutuhan bagi lembaga pesantren. Mutu dalam arti kata, mereka dapat bekerja dengan profesional, sesuai dengan fungsi dan tanggungjawab. Begitu juga bagi pimpinan pondok pesantren dapat bekerja secara profesional untuk memenuhi kebutuhan profesionalisme para ustadz, baik pelayanan, pendidikan, kesehatan, fasilitas, dan yang tidak kalah penting adalah aspek ekonomi atau kebutuhan hidup saat ini dan masa akan datang.

\section{Konsepsi Mutu}

Mutu atau dalam Bahasa Inggrisnya disebut dengan Quality juga dapat dikatakan sebagai kualitas. Definisi konvensional dari kualitas biasanya menggambarkan karakteristik dari suatu produk. Mutu pada dasarnya mempunyai pengertian yang banyak sekali, ini tergantung dari mana orang memandang mutu itu sendiri.

Beberapa pengertian mutu atau kualitas antara lain; mutu atau kualitas adalah segala sesuatu yang mampu memenuhi keinginan atau kebutuhan pelanggan (meeting the needs of customers). (Vincent Gaspersz, 4). Atau 
dapat didefinisikan sebagai sesuatu yang memuaskan dan melampaui keinginan dan kebutuhan pelanggan. (Edward Sallis, 50) Dalam ISO 8402, mutu/kualitas didefinisikan sebagai totalitas dari karakteristik suatu produk yang menunjang kemampuannya untuk memuaskan kebutuhan yang dispesifikasikan atau diterapkan.

Berdasarkan definisi tentang kualitas yang konvensional maupun yang lebih strategik, pada dasarnya kualitas mengacu kepada pengertian sebagai berikut:

1. Kualitas terdiri dari sejumlah keistimewaan produk, baik keistimewaan atraktif yang memenuhi keinginan pelanggan dan dengan demikian memberikan kepuasan atas penggunaan produk itu.

2. Kualitas terdiri dari segala sesuatu yang bebas dari kekuarangan atau kerusakan

Pengertian-pengertian di atas baru hanya pada pendefinisian kata mutu. Lalu apa pengertian dari manajemen mutu. Pada Dasarnya manajemen mutu/kualitas (quality management) atau Manajemen Kualitas Terpadu (Total Quality Management $=\mathrm{TQM}$ ) didefinisikan sebagai suatu cara meningkatkan performansi secara terus-menerus (continuous Performance improvement) pada setiap level operasi atau proses, dalam setiap area fungsional dari suatu organisasi, dengan menggunakan semua sumber daya manusia dan modal yang tersedia. (Vincent Gaspersz, 5-6)

Dalam ISO 8402 manajemen mutu/kualitas sebagai semua aktivitas dari fungsi manajemen secara keseluruhan yang menentukan kebijaksanaan kualitas, tujuan-tujuan dan tanggung jawab, serta mengimplementasikannya melalui alatalat seperti perencanaan kualitas (quality planning), pengendalian kualitas (quality control), jaminan kualitas (quality assurance), dan peningkatan kualitas (quality improvement).

Departemen Pertahanan Amerika Serikat mendefinisikan Manajemen kulaitas terpadu (total quality management) sebagai filosofi dan sekumpulan petunjuk prinsip-prinsip yang menjadi landasan untuk perbaikan terusmenerus dari suatu organisasi. (Vincent Gaspersz, 5-6)

\section{Sejarah Mutu}

Sejarah quality dimulai pada masa bapak manajemen ilmiah frederick taylor pada tahun 1920-an. (Fandi Tjiptono dan Anastasia Diana,5) Namun perkembangan quality tidak berdiri sendiri sebagai kata kunci dalam keberhasilan beberapa negara yang terpuruk dan dapat bangkit lagi melakukan perubahan.

Aspek yang diperkenalkan oleh Frederick taylor yang paling fundamental pada saat itu adalah adanya pemisahan antara perencanaan dan pelaksanaan. Meskipun pembagian tugas telah menimbulkan peningkatan besar dalam hal produktivitas, sebenarnya konsep pembagaian tugas tersebut telah menyisihkan konsep lama mengenai keahlian/keterampilan, di mana individu yang sangat terampil melakukan semua pekerjaan yang dibutuhkan untuk menghasilkan produk yang berkualitas. Manajemen ilmiah Taylor mengatasi hal ini dengan membuat perencanaan tugas manajemen dan tugas tenaga kerja. Untuk mempertahankan kualitas produk dan jasa yang dihasilkan, maka terbentuklah depatemen kualitas yang terpisah.

Sejarah menunjukkan bahwa kebangkitan jepang dalam bidang industri setelah kekalahannya dalam perang Dunia II, dimulai dengan pembangunan sistem kualitas modern. Memang kebangkitan jepang tersebut banyak dipengaruhi oleh sistem yang diperkenalkan oleh W. Edwards Deming yang bicara di hadapan para ilmuawan dan insinyur Jepang pada Tahun 1950. (Fandi Tjiptono dan Anastasia Diana,5) keberhasilan yang dramatis dari industri Jepang dalam meningkatkan kualitas ini menjadi pusat 
perhatian berbagai negara di dunia yang tertarik untuk mempelajari bagaimana strategi perusahaan-perusahaan Jepang dalam menerapkan manajemen kualitas.

Dari hasil studi tentang keberhasilan perusahaan-perusahaan Jepang yang berkelas dan berkualitas, ternyata keberhasilan mereka karena telah menerapkan dan mengembangkan konsep kualitas dalam perusahaan. Kemudian lahirlah apa yang disebut dengan Manajemen Kualitas Terpadu (Total Quality Management).

Namun untuk lebih jelas bagaiman perkembangan kualitas dan pengakuan oleh banyak orang, yang digagas Frederick Taylor dan Edwards Deming. Berikut tabel perkembanganya; (Fandi Tjiptono dan Anastasia Diana,7)

\begin{tabular}{|l|l|}
\hline Tahun & \multicolumn{1}{|c|}{ Kejadian bersejarah } \\
\hline 1911 & $\begin{array}{l}\text { Frederick W. Taylor } \\
\text { mempublikasikan bukunya the } \\
\text { principles of scientific } \\
\text { Management, yang melahirkan } \\
\text { berbagai teknik seperti studi } \\
\text { waktu dan gerak. }\end{array}$ \\
\hline 1931 & $\begin{array}{l}\text { Walter A. Shewhart dari Bell } \\
\text { Laboratories memperkenalkan } \\
\text { statictical quality control dalam } \\
\text { bukunya Economic Control of } \\
\text { Quality of manufactured Product. }\end{array}$ \\
\hline 1940 & $\begin{array}{l}\text { W. Edwards Deming membantu } \\
\text { U.S. Bureau of census dalam } \\
\text { menerapkan teknik-teknik } \\
\text { sampling. }\end{array}$ \\
\hline 1941 & $\begin{array}{l}\text { W. Edwards Deming } \\
\text { mengajarkan teknik-teknik } \\
\text { pengendalian kualitas U.S. War } \\
\text { Department. }\end{array}$ \\
\hline 1950 & $\begin{array}{l}\text { W. Edwards Deming } \\
\text { mengajarkan mata kuliah } \\
\text { mengenai kualitas kepada para } \\
\text { ilmuwan, insinyur, dan eksekutif } \\
\text { perusahaan Jepang. }\end{array}$ \\
\hline 1951 & $\begin{array}{l}\text { Joseph M. Juran } \\
\text { mempublikasikan buku berjudul } \\
\text { Quality Control Handbook }\end{array}$ \\
\hline
\end{tabular}

\begin{tabular}{|c|c|}
\hline 1961 & $\begin{array}{l}\text { Martin Company (kemudian } \\
\text { bernama Martin-Marietta) } \\
\text { membangun rudal pershing yang } \\
\text { memiliki tingkat kerusakan nol. }\end{array}$ \\
\hline 1970 & $\begin{array}{l}\text { Philips Crosby memperkenalkan } \\
\text { konsep zero defects }\end{array}$ \\
\hline 1979 & $\begin{array}{l}\text { Philip Crosby mempublikasikan } \\
\text { bukunya yang berjudul Quality is } \\
\text { Free }\end{array}$ \\
\hline 1980 & $\begin{array}{l}\text { Siaran dokumentasi TV if japan } \\
\text { can.... why can't we? Memberi } \\
\text { pengakuan kepada W. Edwards } \\
\text { Deming di USA. }\end{array}$ \\
\hline 1981 & $\begin{array}{l}\text { Ford Motor Company } \\
\text { mengundang W. Edwards Deming } \\
\text { untuk berbicara di hadapan } \\
\text { eksekutif puncaknya, yang } \\
\text { mempelopori hubungan } \\
\text { produktif antara produsen mobil } \\
\text { dan pakar kualitas }\end{array}$ \\
\hline 1982 & $\begin{array}{l}\text { W. Edwards Deming menerbitkan } \\
\text { buku berjudul quality, } \\
\text { productivity, and competitive } \\
\text { management. }\end{array}$ \\
\hline 1984 & $\begin{array}{l}\text { Philip Crosby menerbitkan buku } \\
\text { berjudul Quality without tears; } \\
\text { the art of hassle-free management. }\end{array}$ \\
\hline 1987 & $\begin{array}{l}\text { Kongres amerika serikat } \\
\text { menetapkan Malcolm Baldrige } \\
\text { National Quality Award. }\end{array}$ \\
\hline 1988 & $\begin{array}{l}\text { Secretary of defense frank carlucci } \\
\text { memerintahkan U.S. } \\
\text { Departement of defense untuk } \\
\text { mengadopsi total quality. }\end{array}$ \\
\hline 1989 & $\begin{array}{l}\text { Florida Power and Light berhasil } \\
\text { menjadi perusahaan non Jepang } \\
\text { pertama yang berhasil } \\
\text { memenangkan Deming Prize }\end{array}$ \\
\hline 1993 & $\begin{array}{l}\text { Total Quality Approach diajarkan } \\
\text { di universitas-universitas di } \\
\text { Amerika Serikat }\end{array}$ \\
\hline
\end{tabular}

\section{Konsep Guru}

Dalam kamus besar bahasa indonesia, guru adalah orang yang pekerjaannya (mata pencahariannya, profesinya) mengajar. (Moeliono, 288). 
Guru menurut pandangan tradisional adalah seorang yang berdiri di depan kelas untuk menyampaikan ilmu pengetahuan. (Roestiyah NK, 182)

Pada dasarnya sebutan untuk orang yang mengajarkan ilmu kepada orang lain mempunyai sebutan yang bermacammacam. Dalam bahasa indonesia sebutan guru, dosen, ustadz, tutor, kyai adalah istilah yang sering didenganr. Dalam Bahasa Inggris dijumpai beberapa kata yang berdekatan artinya dengan pendidik. Kata tersebut seperti teacher yang diartikan guru atau pengajar dan tutor yang berarti guru pribadi atau guru yang mengajar di rumah. Dalam bahasa Arab dijumpai kata ustadz, mudarris, mu'allim, dan mu'addib. Namun secara umum, kalau berbicara tentang pendidikan Islam, maka beberapa istilah yang sering muncul antara lain: ustadz, mu'allim, murabby, mursyid, mudarris, dan mu'addib. (Muhaimin, 44)

Kata-kata dan istilah yang bervariasi tersebut menunjukkan adanya perbedaan ruang gerak dan lingkungan dimana pengetahuan dan ketrampilan tersebut diberikan. Istilah-istilah tersebut walaupun berbeda, namun semuanya mengarah kepada transfer keilmuan dari seseorang kepada orang lain.

Namun dilihat dari kata-kata pendidikan sendiri yang dalam bahasa arab disebut dengan Tarbiyah. Maka Murabbi sebagai isim fa'il dari rabba Yarubbu yang bermakna memperbaiki, mengurusi kepentingan, mengatur, menjaga, dan memperhatikan dan ini lebih dekat, walaupun tidak menafikan makna istilah yang ada. (Abdurrahman anNahlawi, 20)

\section{Syarat dan Sifat Guru}

Seorang ustadz yang bermutu dan berkualiats, maka tentu harus mempunyai sifat-sifat tertentu yang mencerminkan ia sebagai ustadz. Agar seorang ustadz dapat menjalankan fungsinya sebagaimana yang telah dibebankan oleh Allah kepada Rasul dan pengikutnya, maka seorang ustadz harus memiliki sifat-sifat antara lain:
1) Memiliki sifat Rabbani.

2) Ikhlas karena Allah subhanahu wa ta'ala.

3) Mengajarkan ilmu dengan sabar.

4) Memiliki kejujuran dalam menyamoaikan ilmu

5) Selalu meningkatkan wawasan, pengetahuan, dan kajiannya.

6) Pendidik harus terampik, cerdik dalam menciptakan metode pengajaran yang variatif.

7) Seorang guru harus mampu bersifat tegas dan meletakkan sesuatu pada proporsinya.

8) Seorang guru harus peka terhadapa fenomena yang berdampak buruk bagi peserta didik.

9) Seorang guru harus memiliki sikap adil terhadap seluruh anak didiknya. (Abdurrahman an-Nahlawi, 170175)

Zakiah Darajat sendiri sebagaimana yang dikutip oleh Djamarah memberikan persyaratan guru sebagai berikut:

1) Takwa Kepada Allah Subhanahu Wata'ala

2) Berilmu

3) Sehat Jasmani dan Rohani

4) Berkelakuan Baik. (Syaiful Bahri Djamarah, 32-34).

\section{Tugas-Tugas Guru}

Sebagai pendidik di pesantren dapat disebut ustadz. Seorang ustadz dalam kesehariannya adalah sebagai orang yang memberikan dan mentransfer keilmuannya kepada siswa. Namun secara khusus, seorang ustadz mempunyai tugas sangat berat yang ia harus pertanggungjawabkann kepada Allah, dirinya sendiri, lembaga pendidikam, masyarakat, dan lingkungannya. Oleh karena itu, guru harus mempunyai kemampuan-kemampuan yang dapat menyelesaikan tugas khususnya tersebut.

Ustadz memiliki beberapa fungsi, diantaranya; pertama, fungsi penyucian, 
artinya seorang guru berfungsi sebagai pembersih diri, pemelihara diri, pengembang, serta pemelihara fitrah manusia. Kedua, fungsi pengajaran; artinya seorang guru berfungsi sebagai penyampai ilmu pengetahuan dan berbagai keyakinan kepada manusia agar mereka menerapkan seluruh pengetahuannya dalam kehidupan seharihari. (Abdurrahman an-Nahlawi, 170-175)

Dalam konteks keIndonesiaan, menurut Roestiyah N.K. bahwa guru dalam mendidik anak didik bertugas untuk:

1) Menyerahkan kebudayaan kepada anak didik berupa kepandaian, kecakapan, dan pengalamanpengalaman.

2) Membentuk kepribadian anak yang harmonis, sesuai cita-cita dan dasar negara kita pancasila.

3) Menyiapkan anak mejadi warga negara yang baik.

4) Sebagai perantara dalam belajar

5) Sebagai pembimbing untuk membawa anak didik ke arah kedewasaan.

6) Guru sebagai penghubung antara sekolah dan masyarakat.

7) Sebagai penegak disiplin.

8) Guru sebagai administrator dan manajer.

9) Pekerjaan guru sebagai profesi

10) Guru sebagai perencana kurikulum

11) Guru sebagai pemimpin (guidance worker)

12) Guru sebagai sponsor dalam kegiatan anak-anak. (Syaiful bahri Djamarah, 38-39)

\section{Landasan Preskriptif Mutu Guru Pondok Pesantren}

\section{Landasan Religius}

Dalam agama peran seorang guru sangat penting, karena itu banyak ayat dan hadis yang memberikan posisi sangat utama bagi seorang guru. Beberapa hadis yang memberikan gambaran peran dan mulainya seorang guru adalah:

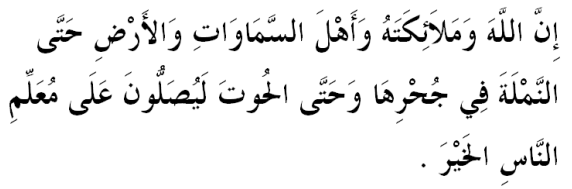

Artinya: " sesungguhnya Allah, para Malaikat, penduduk langit dan bumi, bahkan hingga semut di lobangnya, dan bahkan hingga ikan di lautan, benar-benar memohonkan do'a bagi orang yang megajarkan kebaikan kepada manusia." (HR. Ibnu Abdil Barr, 42)

Dari dalil di atas bahwa kedudukan seorang guru sangat mulia di mata Allah dan Makhluk. Dan bahkan dengan keutaman-keutamaan seorang guru di mata agama, sampai-sampai seorang guru hampir sama peran dan tugasnya dengan seorang rasul.

\section{Landasan Yuridis}

Pondok pesantren saat ini sudah tidak lagi dipandang sebelah mata oleh pemerintah. Keberadaannya yang sangat penting dari semenjak zaman perjuangan sampai saat ini telah melahirkan tokohtokoh penting di negeri ini. Oleh karena itu, pondok pesantren walapun eksistensinya berada di bawah kendali para kyai, namun diberikan persamaan hak oleh pemerintah dalam proses pembelajarannya. Tidak hanya sekedar proses pembelajaran klasikal, tapi proses belajar mengajar non-klaiskal juga telah diakui oleh undang-undang. Dalam Undang-undang sitem pendidikan nasional Bab VI Jalur, Jenjang dan jenis Pendidikan pada bagian kesembilan Pendidikan Keagamaan pasal 30 Ayat 3 dan 4 .

Dengan diakuinya pendidikan pesantren, baik formal maunpun informalnya, maka secara otomatis orangorang yang terlibat di dalamnya juga diakui oleh undang-undang. Terlebih lagi adalah guru yang mengajarkannya. Dan bahkan dalam bahkan dalam pasal 26 ayat 6 dan pada pasal 27 ayat 2, lembaga pendidikan nonformal dan informal dapat 
diakui dengan formal setelah mengikuti dan lulus sesuai dengan standar kelulusan nasional. Maka dengan diakuinya proses belajar mengajarnya, secara otomatis juga guru yang mengajar, baik di formal, nonformal, dan informal pondok pesantren harus profesional.

Berkaitan dengan mutu sendiri, ini jelaskan dalam peratutan menteri pendidikan Nasional nomor 63 Tahun 2009 tentang sistem penjaminan mutu pendidikan pada bab I Pasal 1 ayat kedua yang berbunyiPenjaminan mutu pendidikan adalah kegiatan sistemik dan terpadu oleh satuan atau program pendidikan, penyelenggara satuan atau program pendidikan, pemerintah daerah, Pemerintah, dan masyarakat untuk menaikkan tingkat kecerdasan kehidupan bangsa melalui pendidikan.

\section{Landasan Filosofis}

Setiap bangasa yang ingin maju dan berkembang harus menggarap sektor pendidikan dengan baik. Kemajuan bangsa-bangsa dari sejak dahulu dan dapat bertahan sampai saat ini dikarenakan mutu pendidikan yang baik, yang dapat membentuk karakter bangsanya. Untuk mendapatkan pendidikan yang bermutu, maka mesin pendidik yaitu guru juga dari sumber daya yang bermutu. Tidak mungkin pendidikan berjalan dengan baik kalau tidak ada para guru yang melakukannya dengan baik. Maka mutu guru menjadi hal yang sangat pendting untuk bisa mendapatkan pendidikan yang bermutu.

\section{Landasan Deskriptif Mutu Guru Pondok Pesantren}

\section{Landasan Historis}

Dalam perjalanan sejarah Islam, proses dakwah Rasulullah tidak dapat dilepaskan dari sejarah pendidikan Islam. bahkan buku-buku sejarah pendidikan islam selalu memulai dengan proses dakwah rasul dari dakwah Sirr sampa dengan Jahr, mulai dari kota Makkah sampai setelah hijarah ke kota Madinah.

Dari proses hijrah ini dimulai era baru dalam dunia pendidikan Islam. terutama pada saat perkembangan agama islam pada masa Muawiyah sampai dengan keruntuhan Khilafah Turki Ustmani.

Dalam sejarah banyak diceritakan seperti Imam Syafi'i yang melakukan rihlah thalab Ilmi, dengan berguru kepada banyak syaikh, mulai dari disiplin keilmuan yang paling mendasar sampai hal-hal yang sifatnya sosial kemasyarakatan, dengan itu pula ia dapat memberikan fatwa dalam masalah fiqih. Imam al-Raazi mengatakan bahwa guru Imam Syafi'i jumlahnya cukup banyak. "kami hanya menyebutkan guru-guru dari kalangan ahli fiqih dan fatwa yang terkenal saja. dalam karya ayahku, Imam Dhiyauddin 'Umar bin al-Ha>an menyebutkan jumlahnya 19 guru, di antaranya 5 berasal dari Makkah, 6 berasal dari Madinah, 4 berasal dari Yaman, dan 4 berasal dari Irak. (Ahmad Nahrawi Abdus Salam al-Indunisi, 36).

Gambaran di atas memberikan sejarah panjang keberadaan seorang guru bagi mereka yang menginginkan ilmu yang luas dan bermanfaat. Tidak puas dengan ilmu yang sudah didapatkan, tapi mencari ilmu tidak terbatas pada waktu dan ruang tertentu.Dan masih banyak lagi kisahkisah para imam yang melakukan rihlah ilmu dengan belajar di beberapa guru. Mereka tidak memandang apakah guru tempat ia belajar memberikan manfaat bagi dirinya atau tidak.

\section{Landasan Psikologi}

Menjaga muru'ah seorang ustad adalah hal yang paling penting dalam dunia pendidikan islam, karena ustad dianggap sebagai orang yang sempurna dalam segala hal. Pada tataran interaksi dengan yang lainnya, ustadz tentu tidak sama dengan santri, sehingga perbedaan pemikiran pun hal yang wajar. Seperti posisi kyai yang tentu sangat berbeda dengan santri. Pada saat seseorang berada di atas orang lain, maka secara emosional pun kan berbeda dengan orang lain. Seorang ustadz tidak dapat menampakkan hal-hal yang kurang dari dalam dirinya, maka ia harus terlihat perfect di depan 
para santri, baik tata cara pergaulan, bicara, pakain, dan lain sebagainya. Sama halnya dengan kyai yang memberikan standar tertentu kepada santri agar berbeda dengan dirinya.

\section{Manajemen Mutu Guru di Pondok Pesantren}

Untuk melakukan analsis dan supaya dapat membedakan beberapa prisnsip ada dua hal yang perlu ditekankan pada masalah ini. Pertama, adalah berkaitan dengan perubahan mindset pada pondok pesantren itu sendiri, tanpa harus merupabah status pondok pesantren, tapi perubahan satu hal saja yang berkaitan dengan proses bagaimana mutu ustadz dapat tercapai agar pondok pesantren dapat bertahan dengan baik. Kedua, bagaimana pondok pesantren melakukan sebuah pembinaan agar mutu ustad/guru pondok pesantren sesuai dengan cita-cita dan amannah bangsa. Sehingga akan tercapai pendidikan yang berkualitas dan lulusan yang berkualitas.

Pada bagian yang pertama sampai pada bagian yang ke empat, penulis akan memaparkan analisa tentang bagaimana merubah mindset pondok pesantren terlebih dahulu, kemudia pada bagian yang kelima bagaimana pondok pesantren melakukan pembinaan mutu kepada para guru.

\section{Kondisi Guru Pondok Pesantren}

Tidak dapat dipungkiri bahwa keberadaan pondok pesantren di nusantara ini mempunyai peranan penting dalam perkembangan pendidikan di Indonesia.

Sejak zaman penjajahan, pondok pesantren dan lembaga pendidikan keagamaan lainnya ikut serta dalam usaha mengusir penjajah di nusantara. Karena pondok pesantren sifatnya lebih tertutup dari dunia luar, banyak hal yang dapat dilakukan oleh masyarkat pesantren. Sebagai contoh; latihan ketangkasan yang menjadi kurikulum wajib bagis etiap pondok pesantren, sehingga dari pesantren banyak muncul aliran-aliran silat di nusantara ini.

Namun perkembangan pesantren dalam sejarahnya ada satu unsur yang sering dilupakan oleh hampir semua peneliti tentang pesantren yaitu guru atau ustad. Dari beberapa penelitian tentang pesantren, bahwa unsur-unsur sebuah lembaga pesantren dikatan sebagai sebuah pesantren adalah; kyai, santri, Masjid, dan Asrama. Unsur guru atau ustadz tidak pernah tercatat dalam sejarah pondok pesantren padahal posisinya dalam perkembangan pesantren tidak kalah pentingnya.

Ada yang beranggapan bahwa unsur ustadz ada pada diri seorang kyai. Memang, kyai juga berperan sebagai seorang guru, tapi apakah proses transfer pengetahuan hanya ada pada kyai?, kalau hanya dengan beberapa puluh orang santri, masih memungkinkan kyai dapat berperan ganda, sebagai seorang kyai yang memimpin dan seorang kyai yang bertugas sebagai pengajar/mua'allim atau ustadz. Namun dengan jumlah santri yang banyak, tidak mungkin hanya seorang kyai yang berperan mengajarkan semua disiplin keilmuan dalam pondok pesantren.

Seorang kyai pada dasarnya berfungsi sebagai Muballigh, Mu'allim, dan Manajer, tetapi ustad dalam pondok pesantren berfungsi sebagai seorang mu'allim bahkan yang lebih mendalam adalah sebagai seorang murabbi, orang yang melakukan kontrol selama santri berada di dalam pondok. (Hamdan Farchan dan Syarifuddin, 51).

Apalagi dengan perkembangan pondok pesantren saat, maka peranan seorang guru atau ustadz menjadi sangat urrgen dan kyai lebih banyak pada posisi manajer walapun dalam waktu-waktu tertentu sebagai seorang mu'allim.

Ustadz yang dimaksud di sini adalah mereka yang menjalankan ruh pondok pesantren yang selama ini menjadi adalan pondok pesantren yaitu pendidikan salafiyah/Diniyah. Kalau pendidikan 
formal di madrasah dengan secara alami sudah terjaring dengan sendirinya melalui profesionalisme setiap guru dalam setipa mata pelajaran.

Meraka yang melakukan pelayanan kepada santri selama 24 jam sering terabaikan, terutama pada pondokpondok pesantren salafiyah yang masih membawa pemahaman ikhlas karena Allah ta'ala tanpa menuntut apapun dari seorang kyai. Berbeda dengan pondok pesantren khalafiyah atau modern yang sudah menerapkan sistem manajemen yang mengikuti perkembangan zaman, guru atau ustadz mereka mendapatkan perlakuan yang lebih baik, dari pelayanan, kedudukan, pendidikan, dan ekonomi.

\section{Kedudukan Guru Pondok Pesantren}

Posisi ustadz di pondok pesantren Darussalam Bermi Lombok Barat sama saja dalam dunia pendidikan pondok pesantren pada umumnya, baik salafiyah maupun khalafiyah sangat urgen. Karena berjalan dan tidaknya proses belajar mengajar tergantung dari guru atau ustadz. Tidak lagi kyai yang berperan dalam proses transfer ilmu, kyai saat ini lebih banyak berfungsi sebagai manajer yang hubungannya lebih kepada bagaimana pihak luar menhetahui eksistensi dari pondok pesantren. Sehingga tidak jarang, kyai sebagai pimpinan pondok hanya sebatas "formalitas" sedang eksistensinya berada di luar pondok pesantren. Apakah sebagai politikus, pejabat, muballigh, dan atau bahkan artis?.

Namun keberadaan mereka, terutama dalam pondok pesantren yang masih tradisonal atau salafiyah menggap bahwa mereka yang berstatus sebagai ustadz berada di bawah kendali kyai yang dalam anggapan kyai masih menjadi santri. Dan kalaupun mereka tidak berstatus sebagai santri, tapi mereka masih dalam kategori thalabul ilmi, sedang fungsi pengajaran yang mereka jalankan hanya sebatas khadimun lil syaikh, sebatas ketundukkan dan pengkhidmatan kepada kyai.
Akibatnya peran ustadz dianggap tidak ada di mata kyai, dan mereka diperlakukan seperti layaknya santri. Harus taat kepada kyai sebagaimana santri lainnya, terutama kewajibankewajiban yang harus dilakukan sebagai seorang santri. Pada batas-batas ruang lingkup agama mungkin masih ditolerir, namun dalam masalah-masalah iktiyar manusia, maka ustadz harus dapat diperlakukan dengan baik.

Dalam dunia pondok pesantren sangat masyhur yang namanya muru'ah (kehormatan), sesuai dengan posisi dan kedudukannya. Kalau sikapnya bertentangan dengan posisi dan kedudukannya, maka muru'ahnya sudah hilang di mata orang-orang disekitarnya. Seorang kyai atau pimpinan pondok akan selalu menampakkan kewibawaannya di kalangan santri atau masyarakat lainnya, baik tata cara berbicara, berpakaian, berjalan, bahkan perlakuan orang kepadanya. Dengan menjaga hal-hal tersebut, maka ia layak mendapatkan predikat orang alim dan profesional sebagai kyai. Jika hal-hal terebut ia tanggalkan, maka secara otomatis keprofesionalannya sebagai seorang kyai akan turun, bahkan orang-orang tidak akan menyebutnya sebagai seorang kyai.

Begitu juga dengan seorang guru atau ustadz, mereka mempunyai posisi yang sangat berbeda dengan santri dan tidak melampui posisi kyai. Dengan posisi yang berbeda tersebut, maka seorang guru atau ustadz juga harus dapat menampakkan eksistensinya sebagai seorang guru atau ustadz. Pada saat seorang kyai memperlakukan guru atau ustadz sama seperti santri, maka secara otomatis muru'ah dan eksistensi sebagai seorang ustadz yang professional akan luntur. Sebagai contoh seorang kyai memberikan hukuman kepada seorang ustadz di depan santri, atau menyuruh untuk menyapu halaman, atau mencuci pakaian kyai. Memang contoh di atas tidak mutlak salah, namun dengan perlakuan seperti itu akan mengurangi muru'ah seorang ustadz di mata para santri. 


\section{Pelayanan dan Fasilitas}

Penghargaan seorang ustadz pada pondok pesantren salafiyah oleh kyai atau para pendiri pondok pesantren sangat tidak layak. Mereka diposisikan sama dengan santri lainnya yang harus tunduk kepada keputusan kyai dan menerima apa adanya sebagaimana tradisi pesantren terdahulu.

Memang seorang kyai adalah posisi sentral dalam pondok pesantren dan mempertahankan tradisional pondok dalam kajian-kajian keilmuan harus tetap dipertahankan, terutama kajian-kajian kitab kuning. Tapi dalam pengembangan pesantren harus dilakukan perubahanperubahan yang lebih baik, terutama peran sentral kyai yang saat ini sudah tidak mutlak, bahkan aktivitas kyai sudah banyak tidak fokus kepada pondok pesantren, sehingga yang banyak berperan adalah pada pengasuh, baik dari kalangan guru atau ustadz atau santri senior.

Di pondok-pondok tradisional banyak ditemukan nasib para guru atau ustadz yang sangat memprihatinkan. Mereka masih didoktrin dengan keihklasan untuk mengabdi, tanpa mengharap pamrih, tapi kyai dengan usahanya sendiri memperkaya diri sendiri. Bukan hanya saja pondok pesantren yang masih "miskin" dan "terbelakang", tapi beberapa pondok pesantren yang "kaya" dan "maju" namun masih mempertahankan tradisional, mereka memperlakukan ustadz engan tidak layak, padahal mereka mengabdi 24 jam untuk mengurus santri. Apalagi fasilitas lainya seperti telpon, internet dan lain sebagainya. Mereka untuk memenuhi kebutuhan sehari-hari harus beli, sedang honorarium dari pondok pesantren tidak seberapa bahkan tidak ada.

Untuk dapat menjaga dan meningkatkan mutu para ustadz di pondok pesantren tentu harus dengan memberikan pelayanan dan fasilitas yang lebih baik. Pelayanan dalam arti sebagai seorang ustadz, maka harus ada perbedaan dengan santri agar mereka dapat betah dan fokus dengan pelayanan pendidkan untuk santri. Beberapa pelayanan yang harus dibedakan antara lain pelayanan kebutuhan sehari-hari seperti makan, minum, dan lain-lainnya yang bersifat pelayanan.

Makan dan minum adalah kebutuhan primer bagi setiap orang, apalagi seorang ustadz yang bekerja full time mengurus dan mendidik santri. Maka seharusnya mereka diberikan layanan kosumsi yang lebih baik. Pada pondokpondok pesantren salafiyah ustadz ditelantarkan begitu saja dalam urusan makan dan minum. Mereka harus berusaha sendiri untuk memenuhi kebutuhan sehari-hari, apakah dengan membeli nasi seperti santri lainnya atau memasak nasi sendiri. Hal ini tentu memberikan beban yang berat, di satu sisi mereka harus ikhlas mengabdikan diri untuk mendidik para santri agar dapat mengusai bidang kajian tertentu, namun di sisi lain mereka harus menahan lapar sesering mungkin. Sedangkan kyai semakin subur, makmur, dan kaya dari hasil penjualan nasi kepada santri.

Sampai saat ini memang masih banyak ditemukan pondok pesantren yang mentolerir santrinya yang masak sendiri. Namun beberapa pondok pesantren sudah tidak mentolerir para santri yang masak sendiri, dengan alasan tidak dapat membagi waktu atau mengotori asrama. Dengan itu, para kyai membuka warung nasi atau dengan cara mewajibkan santri kost makan di kyai. Dengan jumlah santri yang banyak tentu akan mendapatkan laba yang sangat besar, dan kyai semakin kaya dengan transaksi makanan saja. Belum lagi bisnis kantin yang menjual aneka ragam jajanan untuk santri yang 24 jam berada di dalam pondok pesantren. Dan semua aktivitas ekonomi tersebut hanya untuk kebutuhan pribadi kyai saja, dan bukan masuk dalam aktivitas manajemen pondok, sehingga keuntungannya untuk pondok dan bersama.

Dengan keuntungan secara ekonomi kyai dari pondok pesantren, tidak banyak memberikan kontribusi untuk 
kesejahteraan para guru atau ustad. Lebih parah lagi mereka para guru atau ustad tidak mendapatkan gaji, kalau pun ada hanya cukup untuk sabun mandi dan sabun cuci, dan kebutuhan lainnya usaha sendiri atau minta jatah bulanan dari orang tua.

Dari sisi fasilitas ustad yang berada di dalam pondok pesantren dapat dikatakan banyak tidak layak. Sebagai contoh kamar mandi yang tidak tersedia dan tidak disediakan oleh pondok untuk para guru atau ustadz. Kalaupun ada hanya beebrapa saja, dan itu harus berebutan dengan para santri. Tidak ada privasi yang diberikan pondok pesantren untuk menjaga izzah dan muru'ah mereka di depan para santri.

Dapat dibayangkan saat ini, mereka yang harus mengajar pagi hari dan sudah berada di tempat mengajar sebelum para santri datang, sedangkan mereka harus antri mandi pagi dengan santri yang lainnya. Ini tentu secara psikologis memberikan dampak yang tidak baik dalam diri seorang guru atau ustad.

Dengan keadaan seperti ini, para guru atau ustadz menjadi sebuah dilema. Di satu sisi mereka dituntut untuk mengabdi lillahi ta'ala, tapi di sisi lain mereka harus memikirkan kebutuhan sehari-hari mereka. Untuk meminta kepada orang tua, tentu mereka malu, karena mereka sudah menyandang status guru atau ustadz. Merekalah yang seharusnya memberikan uang kepada kedua orang tua. Atau mereka ingin keluar dari pondok pesantren, namun mereka juga takut "kualat" karena tidak taat dan tunduk kepada kyai.

\section{Pemberdayaan Ekonomi}

Pada dasarnya, secara ekonomi, pondok pesantren mempunyai potensi yang sangat besar. Apalagi mereka yang menyandang status pondok maju.

Keberadaan pondok pesantren di nusantara ini tidak terlepas dari harta kyai yang mereka rata-rata mempunyai staus sosial tinggi. Tidak hanya dari ketururnan, tapi dari segi harta benda mereka juga tergolong orang-orang kaya. Bahkan menyandang status terkaya di tempatnya. Maka tidak salah jika potensi ekonomi pondok pesantren juga besar. Di tambah lagi dengan iming-iming "pahala" bagi mereka yang berinfak, shadaqah, berzakat, dan yang paling populer adalah berwaqaf. Banyak kemudian masyarkat menyerahkan harta mereka kepada pondok pesantren.

Ustadz di pondok pesantren kalau hanya memikirkan dan mengandalkan gaji yang diberikan pondok pesantren, apalagi mereka yang sudah berkeluarga, maka secara matematis tidak akan pernah mungkin dapat menghidupi keluarganya.

Seharusnya, seorang kyai tidak mencampuradukkan harta pribadi yang menjadi hak miliknya dengan hartanya yang telah diwaqafkan untuk umat Islam dan harta kaum muslimin yang diperuntukkan kepada pondok pesantren. Tapi bagaimana harta tersebut menjadi harta bersama dalam memajukan pondok pesantren. Sebagai contoh kecil potensi ekonomi santri yang dimiliki oleh pondok pesantren. Dengan medirikan warung/kantin kecil yang dimiliki oleh semua bukan milik pribadi kyai, maka potensi ekonomi guru atau ustadz dapat diberdayakan. Tanpa harus mengandalakan dari pihak luar, potensi guru atau ustadz yang sudah berkeluarga dapat diberdayakan. Atau dengan membagi-bagi jumlah santri yang makan, setiap guru atau ustadz yang sudah berkeluarga dititipkan beberapa orang santri untuk makan, maka ini juga dapat memberikan tambahan ekonomi yang baik bagi guru atau ustad.

Dengan pemberdayaan tersebut maka guru atau ustadz yang berada di pondok pesantren akan dapat fokus untuk mengajar dan mendidik, tanpa harus dipusingkan dengan masalah ekonomi untuk menghidupi keluarga. Mereka tidak terbagi pikirannya ke laur pondok pesantren untuk mengajar di tempat lain, atau berbisnis setelah mengajar, atau melakukan aktivitas di luar kegiayan pondok pesantren. Dengan jaminan 
ekonomi tersebut, maka mereka fokus untuk mengembangkan dan memajukan pondok pesantren, kalau tidak dilakukan hal seperti itu, maka sedikit demi sedikit guru atau ustadz yang mempunyai potensi baik akan memilih keluar dari pondok pesantren.

\section{Pemberdayaan Pendidikan}

Mutu guru atau ustadz dalam makalah ini adalah profesionalime seorang guru dari segi kualifikasi dan hal yang dapat menunjang profesionalime tersebut. Di antara untuk mewujudkan profesionalisme guru tersebut dengan melalui pendidikan yang layak.

Guru atau ustadz dalam dunia pondok pesantren, terutama mereka yang menjadi motor penggerak di dalam pesantren hampir rata-rata dari segi kualifikasi pendidikan hanya sebatas pendidikan pesantren atau mereka hanya tamatan diniyah atau madrasah Aliyah. Namun dengan sumber daya seperti itu, pondok pesantren tetap eksis dengan perkembangan pendidikannya dan masyarakat masih mengakui.

Oleh karena itu, dapat dibayangkan kalau para guru atau ustadz tersebut mempunyai kulaifikasi pendidikan minimal S1 atau bahkan S2 dan S3, maka tentu kemajuan dan berkembang pesatnya pendidikan pondok pesantren.

Namun untuk dapat merealisasikan guru atau ustadz yang mempunyai kualifikasi baik sangat susah. Bukan dari diri ustad/guru sendiri, namun dari pihak pondok pesantren atau kyai.

Mereka para guru atau ustadz bertahan mengabdi dan mengurus dengan keahlian yang telah mereka dapatkan saat diniyah atau madrasah aliyah, atau keahlian yang didapatkan dari autodidak. Namun seiring dengan perkembangan zaman juga, mereka yang telah ahli dalam bidangnya, tapi karena tidak mempunyai kualifikasi sebagai seorang guru, secara perlahan dan pasti tersingkir dari pondok pesantren, digantikan oleh mereka yang mempunyai kualifikasi pendidikan yang baik.
Oleh karena itu, seorang kyai tidak hanya sekedar mengharapkan pengabdian para guru atau ustadz, namun mereka juga harus diberikan hal yang setimpal dengan pengabdian mereka dengan cara pengembangan keilmuan yang layak, seperti memberikan mereka ikut kuliah di ma'had aly secara gratis atau bahkan perguruan tinggi.

Pada dasarnya pemerintah melalui kementrian agama pernah melaukan terobosan untuk peningkatan kualias pendidik di pesantren dengan memberikan pendidikan gratis pada tingkat strata 1 dan strata 2 . Pada awalnya mendapatkan sambutan yang baik oleh pondok pesantren, namun seiring berjalannya waktu menjadi bertepuk sebelah tangan. Pada tataran strata 1, pondok pesantren lebih banyak memilih memberikan rekomendasi pada orangorang yang ada hubungan kekeluargaan dengan kyai, walaupun secara potensi tidak baik. Sedang mereka yang mempunyai potensi baik dari kalangan santri, tapi karena tidak ada hubungan kekluargaan, mereka tidak bisa ikut.

Yang tidak kalah mengherankan adalah para guru atau ustadz yang melanjutkan ke strata 2. Pada awalnya kementrian agama mempunyai cita-cita besar terhadap perkembangan pendidikan pondok pesantren ke depan. Yaitu bagaimana pendidikan pondok pesantren dapat bersaing dengan pendidikan umum yang bernaung di bawah kemendikbud. Dengan cara memberikan beasiswa kepada guru atau ustad pondok pesantren untuk melanjutkan ke strata 2 dari semua disiplin ilmu dan ditempatkan di universitas-universitas berkualitas negeri ini. Dengan harapan dalam beberapa tahun semua guru di pondok pesantren dari disiplin keilmuan yang berbeda telah ada guru atau ustadz S2. Dan secara otomatis beberapa madrasah di negeri ini dapat menjadi madrasah rintisan internasional atau bahkan madrasah bertaraf internasional. Dengan melihat kualifikasi guru atau ustad yang dipunyai pondok pesantren. 
Namun program tersebut hanya dapat berjalan sekitar 3 tahun, karena banyak sekali pondok-pondok pesantren yang tidak kooperatif dengan guru atau ustad mereka yang menempuh S2. Mereka yang mendapatkan beasiswa secara otomatis tersingkir dari pondok pesantren , padahal mereka posisinya tugas belajar dari pondok pesantren. Dengan banyaknya keluhan dan penyesalan dari mereka yang menenpuh S2 kepada pondok pesantren, akhirnya program beasiswa S2 kemenag dialihkan lagi ke perguruan tinggi.

Dari masalah tersebut, maka terlihat bagaimana tidak kooperatifnya pondok pesantren dalam pengembangan kualitas pendidik dan pendidikan di pesantren.

Untuk itu pada dasarnya ada beberapa hal yang memungkinkan untuk dilakukan pondok pesantren dalam upaya meningkatkan mutu ustad/guru, antara lain;

1. Mensarjanakan semua ustad/guru dengan disiplin ilmu yang berbedabeda, agar terpenuhinya kebutuhan semua mata pelajaran. Pensarjanaan dapat dilakukan dengan mencarikan beasiswa bagi guru atau tugas belajar dengan beasiswa dari pondok pesantren.

2. Memberikan pelatihan-pelatihan di luar pondok pesantren terkait dengan pembelajaran, terutama pengajaran kitab kuning. Dapat bekerjasama dengan pondok pesantren yang sudah maju atau melakukan studi banding.

3. Kyai melakukan pengajaran privat bagi ustad-ustadz yang ada dalam pondok pesantren agar kualitas keilmuan dapat meningkat.

\section{Kesimpulan}

Dari uraian dan pemaparan di atas bahwa peran seorang guru atau ustadz dalam pondok pesantren sangat penting. Karena mereka adalah motor penggerak, oleh karena itu kulitas mereka harus tetap terjaga dan bahkan ditingkatkan dengan:
1. Seorang kyai harus dapat memposisikan guru atau ustadz layaknya mereka seorang pendidik, tidak menyamakan mereka dengan santri. Karena dengan menjaga muru'ah mereka berarti menjaga kualitas dan mutu mereka sebagai seorang guru atau ustadz.

2. Ustadz di pondok pesantren bekerja 24 jam untuk mengurus santri, sehingga hampir sebagian hidup mereka habiskan untuk mengabdikan diri. Oleh karena itu, mereka tidak dapat memikirkan halhal di luar kegiatan pesantren, apalagi masalah ekonomi. Maka seorang kyai harus memberikan fasiltas dan pelayanan yang baik agar mobilitas mereka tidak terhenti dengan berhentinya mereka dari aktivitas pesantren.

3. Agar dapat bersaing dengan dunia pendidikan lainnya, maka kyai juga harus memberikan ruang untuk guru atau ustadz agar dapat meningkatkan potensi, kualitas, dan kualifikasi mereka melalui potensi akademik yang lebih baik. Apakah dengan memberikan besasiswa kepada mereka dari S1 sampai dengan S3 atau mencarikan mereka beasiswa pendidikan. Dengan kualifikasi pendidikan yang baik, maka secara otomatis pendidikan pesantren dapat mencapai pendidikan bertaraf internsional atau paling rendah bertaraf nasional.

\section{Daftar Pustaka}

Al-Syamimiri, Ahmad bin Abdurrahman. 2002. Kaifa Takunu Mu'alliman Najihan. Libanon: Dar Ibn Hazm.

al-Indunisi, Ahmad Nahrawi Abdus Salam. 2008. Ensiklopedi Imam Syafi'i Jakarta: PT Mizan Publika.

an-Nahlawi, Abdurrahman.1995. Usul altarbiyah al-islamiyah wa Asalibaha; fi al-bait wa al-madrasah, wa al- 
mujtama'Jakarta: Gema Insani Press.

Arif, Mahmud. 2008. Pendidikan Islam Transformatif. Yogyakarta: LkiS

Asy- Syalbub, Fu'ad bin Abdul Aziz. 2009. Begini Seharusnya menjadi Guru. Terj. Jakarta: Darul Haq.

Barizi, Ahmad. 2009. Menjadi Guru Unggul. Yogyakarta: Ar-Ruzz Media

Djamarah, Syaiful Bahri. 2000. Guru dan Anak Didik dalam Interaksi Edukatif. Jakarta: PT. Rieneka Cipta.

Elfindri, dkk. 2010. Soft Skill untuk Pendidik. Jakarta: Baduose Media.

Fadjar, Malik. 2005. Holistika Pemikiran Pendidikan. Jakarta: PT. Raja Grafindo Persada.

Farchan, Hamdan dan Syarifuddin. 2005. Titik Tengkar Pesantren; Resolusi Konflik Masyarakat Pesantren. Yogyakarta: Pilar Religia.

Gaspersz, Vincent. 2005. Total Quality Management. Jakarta: PT. Gramedia Pustaka Utama.

Idrus, Ali. 2009. Manajemen Pendidikan Global: Misi, Aksi dan Adaptasi. Jakarta: Gaung Persada Press.

Masyhud, M. Sulthon dan Moh. Khunuridho. 2003. Manajemen Pondok Pesantren. Jakarta: Diva Pustaka.

Muhaimin. 2005. Pengembangan Kurikulum Pendidikan Agama Islam; di sekolah, madrasah, dan perguruan tinggi. Jakarta: PT. Raja Grafindo Persada.

Nata, Abduddin. 2007. Manajemen Pendidikan; Mengatasi Kelemahan pendidikan Islam Indonesia. Jakarta: Kencana Prenada Media Group.

Nizar, Samsul, dkk. 2007. Sejarah Pendiidkan Islam: Menelususri Jejak Sejarah Pendidikan Era Rasulullah sampai Indonesia. Jakarta: Kencana Prenada Media Group.

Nurdin, Syarifuddin dan Basyiruddin Usman. 2003. Guru Profesional dan Implementasi Kurikulum. Jakarta: Ciputat Press.

Saleh, Abdurrahman, dkk. 1982. Pedoman Pembinaan Pondok Pesantren. Jakarta: Depag.

Sallis, Edward. 2010. Total Quality Management in Education. Terj. Yogyakarta: IRCiSod.

Sukmadinata, Nana Syaodih.1997. Pengembangan Kurikulum Teori dan Praktek Bandung: Remaja Rosdakarya.

Tjiptono, Fandi dan Anastasia Diana. 2003. Total Quality Management. Yogyakarta: ANDI. 